\title{
Interaction and Interactivity Process: Communication in Digital Education
}

\author{
Andreia de Bem Machado ${ }^{\mathrm{a}, *} \&$ Francisco Fialho ${ }^{\mathrm{b}}$ \\ ${ }^{a}$ Department of Engineering, FAVIM - UNIASSELVI, Brusque, Brazil \\ ${ }^{b}$ Santa Catarina Federal University, Brazil
}

\begin{abstract}
Communication between subjects is a challenge that is present in the different dimensions of society. In the educational context it is permeated by different technologies. With the pandemic of COVID-19, technological tools have been extended to several ways of learning, which was present in face-to-face teaching through non-face-to-face classes and also in distance education. Thus, new challenges in communicability between students, teachers and knowledge were present in this scenario. This research intends to share the experiences lived in the educational universe in the distance modality and also in the classes in non-presential regime.
\end{abstract}

(C) 2020 Author(s). All rights reserved.

Keywords: Communication; interaction; interactivity.

\section{Introduction}

The educational system linked to changes in society provides a set of transformations, these being linked to the training of teachers, the pedagogical conception, the didactic material used, the training proposed to educators, the different age groups served, as well as the possibility of studying in person. or the distance. In the year 2020, with the COVID-19 pandemic where the measures to contain the virus were social isolation, these changes became more evident.

Thus, both face-to-face and distance learning (DE), had the virtual context as their classroom, cyberspace understood as "the new means of communication that arises from the worldwide interconnection of computers" (Levy, 1999) . This context, mediated by digital platforms that provide synchronous and asynchronous communication between teachers, students and knowledge. This article has as its main objective to evaluate the process of asynchronous interaction and interactivity between student and teacher, by the written language in the virtual learning environment (VLE) and in the digital platforms used in the moments of non-classroom lessons. As questions that guide this objective, we have the identification of asynchronous communication; describe the teaching and learning process in Distance Education (DE) and in the digital platforms used in the moments of non-face-to-face classes based on asynchronous communication; characterize the subjects that make up the AVA and on the digital platforms used in the moments of non-classroom class .; analyze the written language in the process of asynchronous interaction and interactivity in AVA.

Regarding the educational system, the diversity of the proposed models, the methodologies used, the training programs, the possibility of studying in person and/or at a distance are observed. Within these modalities, it is still possible to include the semi-face-to-face model, as well as tele-face.

\footnotetext{
* Corresponding author.

E-mail address: andreiadebem@gmail.com (Andreia de Bem Machado)
} 
According to the scenario presented, the commitment to education is made explicit, which is closely related to reality, to the social context in which the teacher and student live and where the action of knowing is not separate from what is known. Laoni (2009) states that "knowledge is always directed towards something".

\section{The Teaching Learning Process in Distance Education and in Non-Classroom Classes}

The teaching and learning process takes place in the interaction between educator, educating and the mediation of methodological 'instruments' such as books, research activities, experience reporting, exploration of the present socio-cultural and cultural context, among others. Linked to these elements, we find the availability of modalities of classroom and/or distance learning.

By face-to-face teaching, we mean the 'traditional' model, where the face-to-face meeting between educators and students takes place in the pre-determined period and space. It presents as a characteristic, the direct relationship between the subjects involved in this process, having as interactivity the varied expressions of language, whether corporal, written and/or oral. In 2020, face-to-face teaching had to readjust the classes, which were taught on digital platforms in the non-face-to-face modality, mediated by new technologies that enabled communication between students, teachers and knowledge.

The great digital technologies emerged, then, as the cyberspace infrastructure, a new space for communication, sociability, organization and transaction, but also a new market for information and knowledge (Lévy, 1999, p. 32).

As for distance learning, the relationship between educator and student is mediated by communication tools such as correspondence, radio, didactic films, television, and in the last decades, heavily by the computer and via the internet. The advent of the internet allowed access to different sources of knowledge, as well as the development of dynamic VLE. "Allying itself with technology, education will be providing the teacher and the student with a more comprehensive interpretation of the world, allowing both one and the other to transform the knowledge acquired into competence" (BOHN, LUZ and LUZ FILHO, 2010, p. 27 ).

In distance education, it is essential that there is continuous commitment between the subjects involved in this process, these represented by teachers, students, technical staff, tutoring team. In addition to ensuring the presentation of educational materials and complete and motivating virtual environments. In the educational process, whether faceto-face and/or distance, communication is an essential element.

\section{The Role of Communication in the Virtual Learning Process and in Non-Classroom Classes}

Man is a communicative subject rooted historically in a socio-cultural context. From this existence, there is the elaboration of communicational authorship in different degrees and modes of consciousness, of knowledge, of acting as people, at the same time sending and receiving, in the plots of the communication process of culture. (BELLONI, 2009, p. 13).

Communication is based on the existence of two essential elements, the transmitter and the receiver. Mediating this relationship we have the message and the information to be disseminated. This relationship must go beyond the transmission of a message, as communication must enable "sharing meaning." (LÉVY, 1999).

The studies by Possari (2009) and Lévy (1999) point out three different forms of communication identified, they are: from a person to a person in person, via telephone or e-mail; from one person to millions due to the communication processes engendered by the mass media such as printed newspapers/magazines, radio, TV and from millions to millions with the advent of the internet.

In face-to-face education, communication takes place in the same space and time, in personal feedback, in the gestures made between teacher and student. According to Kenski (2004), the face-to-face school is polyphonic where sounds are spread throughout the environment and give meaning to the educational space. In this way, the educator has direct contact with the student, reducing the possibility of confusion in communication, that is, that the message, 
the doubtful shared information takes time to be reviewed, contextualized. However, with the COVID-19 pandemic, communication was mediated by new technologies in non-classroom classes through mobile networks:

[...] the extension of cyberspace accompanies and accelerates a general virtualization of the economy and society. From substances and objectives we return to the processes that produce it. From the territories, we jump towards the source, towards the mobile networks that value and design them. From processes and networks, we move on to the competencies and scenarios that determine them, even more. The media of collective intelligence in cyberspace multiply and synergize skills. From design to strategy, scenarios are fed by simulations and data made available by the digital universe. Ubiquity of information, interconnected interactive documents, reciprocal and asynchronous telecommunication in groups and between groups: cyberspace makes it the vector of an open universe. Symmetrically, the extension of a new universal space expands the field of action of virtualization processes "(LÉVY, 1999, pp. 49-50).

In virtual education, communication is done without body contact, without the physical presence of the individual. In distance education, communication takes place without a defined space, as explained by Kenski (2004, p. 55),

Virtual education (...) is exposed on the computer screen (...) a place where flows and messages are shared for the dissemination of knowledge (...) building new forms of communication, the virtual school space presents itself for the structuring of online communities in which students and teachers talk permanently, mediated by knowledge.

Among the forms of communication that took place in the pedagogical environment, we highlight non-verbal communication for face-to-face teaching and verbal communication for distance education. Non-verbal communication composed of elements, such as gestures, postures, facial expressions, silence, clothing, various objects, established relationships. These forms of communication indicate feelings and emotions that reinforce verbal language, and in some cases replace it. With the COVID-19 pandemic, verbal and non-verbal communication was present in distance education and in classes in the face-to-face modality.

Verbal communication enables expression through writing and/or speaking. These possibilities comprise different spaces of manifestation, which may be a dialogue between two or more people, books, radio, posters, newspapers, letters, phones, e-mails, as well as AVAs and on digital platforms (non-face-to-face classes).

With regard to AVA and digital platforms (non-face-to-face classes), verbal communication has two variables, being synchronous and asynchronous.

In synchronous communication, ideas and information are synchronized. These happen with the support of tools such as chats, forums where questions can be answered promptly, through written communication based on the harmony between the receivers and the senders, in the same time. According to Menezes and Santos (2002), synchronous communication occurs simultaneously and, thus, messages sent by one person are immediately received and answered by other people.

According to Machado and Fialho (2013), asynchronous communication occurs with a time interval between the sending of the message (sender) and access to it (receiver). These messages comprise e-mails, internal mails, messages posted on the AVA - message space, forum, wall. According to Menezes and Santos (2002), asynchronous communication does not happen at exactly the same time, it is non-simultaneous. In this way, the message sent by one person is received and answered later by the others.

In this communication, as the time interval between one message and another is longer, therefore, there is a possibility that there will be a double interpretation of the message and/or the communication will be 'garbled' and, in some cases, the sender will have written something and the receiver to relate the text to another meaning.

This research focuses on asynchronous communication, based on records present in AVAs and the digital platforms of non-classroom classes. The deepening of this study is based on the messages sent to students by the teacher and/or from the student to the teacher, where many of them represent the lack of possibility to clarify what the message really intended to convey, in the communication established between these subjects. Asynchronous communication requires that the subjects involved resort to a clear, punctual, welcoming and based on the set of elements that reinforce the expected result from this interaction. 
Inadequate inferences cause communication noise. With emphasis on the written language, these inferences support the possibilities of misinterpretation of the recorded message, which can feed the conflict between the protagonists of communication.

This conflict, at first, signals a relationship of friction, discomfort and, in some situations, causes the 'disruption' of communication. But, there is the possibility of the conflict being accompanied by another approach where, "the conflict (...) prevents stagnation due to the constant balance of agreement, stimulates interest and curiosity for the challenge of the opposition" (MOSCOVICI, 2008, p. 213).

In this perspective, the conflict promotes contextualization, reflection on the pertinent message. The way in which this 'non-stagnation' is recorded, even if it represents 'protest,' should be composed of clear, coherent and polite language.

\section{Methodological Procedures}

In order to understand the process of interaction and interactivity, between student and teacher focused on the written language that supports AVA, it was decided to carry out qualitative research. Qualitative research is carried out with co-participation between researcher and researched that build the reality that they interpret together (ALEXANDRE, 2009).

As for the nature of the data analysis, the research is identified as descriptive where, "the interpretation of the results appears as a totality of a speculation that is based on the perception of a phenomenon in a context. That is why it is not empty, but coherent, logical and consistent "(TRIVIÑOS, 2011, p. 128). In this case, the phenomenon is linked to communication in the AVA, between teacher and student.

Regarding this research, the documentary source is represented by the written record of the interactions established between teacher and student in the AVA. These records were selected and analyzed, based on asynchronous interactions. As for AVA, its representation includes the Moodle and Webct platforms, which provide support for specialization and master's courses, linked to federal educational institutions. And also from the Classroom platform (google platform) of classes in the non-classroom mode at a public Higher Education Institution.

The selection of the speeches involved the difficulty of establishing communication between the transmitter and the receiver where, the message posted presented a return not coherent with the expected, that is, the interpretation of the subjects involved flowed through different strands.

Within the aforementioned platforms, the AVA and the Classroom platform, access was limited to groups that were in the process of completing courses and undergraduate students, respectively. After checking the speeches, the analysis was scored on five students and six teachers. This differentiated distribution between students and teachers, resulted from the fact that one student interacted with two teachers and one student interacted with three teachers and another three students interacted with one teacher.Within the aforementioned platforms, the AVA and the Classroom platform, access was limited to groups that were in the process of completing courses and undergraduate students, respectively. After checking the speeches, the analysis was scored on five students and six teachers. This differentiated distribution between students and teachers, resulted from the fact that one student interacted with two teachers and one student interacted with three teachers and another three students interacted with one teacher.

\section{Data Presentation and Discussion}

Based on the documentary records present in the AVAs and the Classroom platform studied, it was possible to identify the communication weaknesses present in the asynchronous interaction between teacher and students.

One of the highlighted aspects involves the difficulty of understanding, on the part of the students, regarding the establishment of new didactic and/or regimental proposals, resulting from the revision of the methodology used, by the teachers and by the course coordinators. 
These changes provoked emphatic manifestations by the students and, in some moments, aggressive and threatening; and in other situations of lack of understanding of the activity that is requested, causing weakness in explanations and misinterpretation by students.

The process present in this established asynchronous communication brings us to the subjectivity that comprises each of these subjects, being these transmitters and/or receivers of the message in focus. "The whole process of subjectivity leads to a system of construction of meanings that are inherent to the individual" (LAPOLLI et.al., 2011, p. 233).

In recording one of these interactions, the student used words, such as: "weird"; "demand"; "This is absurd"; "I am going to the last few instances" "I cannot understand" "the teacher is not understanding my work" "I want to change the topic and I cannot understand what is being asked". This set of words represents the record of an interaction that initially proved to be challenging and in the second moment it established itself as aggressive and, in some points, threatening.

As the communication established was asynchronous, it was not possible to provide an instant explanation regarding the presentation of a new methodological proposal.

The way in which the student received the message was understood as disrespecting the activity he had already carried out. On the other hand, the teacher who launched the message and then replied to the student, followed a general update of the methodological proposal, without focusing on the student in question.

As one of the characteristics of asynchronous communication is linked to the establishment of a time difference between the posted message and the access to it by the reader, there is a risk that the information will be interpreted incoherently.

Another highlighted record focuses on questioning the model of the interaction methodology between the institution and the students, in the distance modality and Classroom platform (class in the non-face-to-face modality).

The record of the students analyzed in the AVA and in the Classroom platform (class in the non-face-to-face modality) pointed to some questions such as: I) the model without the establishment of interaction between the student and the teacher where the didactic material was made available, the student decorated the contents and carried out the evaluations; II) the collaborative model where, the development of knowledge occurs with the different cultural manifestations of the students and the sources of study are explored when accessing the internet. With these notes, he criticized the availability of an interaction tool - the Forum and the activities posted in the environment, but little explored.

It was possible to perceive the students 'uneasiness about a request for more active monitoring of the teachers' involvement, both in the distance learning modality and in the classroom classes. At another point, there is a concern of teachers to accommodate the demand of students, but in some cases teachers remain neutral as to the affirmation or denial of the failure in the communication model made available through the platforms, be it AVA or Classroom.

The situations presented here focus on the cultivation of manifestations of conflict where there is "a situation that reveals disagreement, confrontation of opinions, between two or more people, a situation that does not necessarily have to be negative." (AZEVEDO, 2011, p. 3)

From another perspective, these manifestations can contribute to the constant review of methodological resources, interaction tools made available, thus valuing the different representativeness of this process both in distance education and in classroom classes.

\section{Final Considerations}

The national teaching and learning process has undergone major transformations, from the determination of which social class could access it, the reformulation of the period of permanence in schools to the COVID-19 pandemic that led to social isolation passing to remote education through non-face-to-face classes. 
These changes also include the distance modality in terms of the offer of different courses, at different levels of degrees, as well as the availability of wide AVA composition platforms. And also the readjustment of classroom teaching in the use of information and communication technologies and the readjustment for the use of digital platforms, including Classroom.

Guiding this movement, we find asynchronous communication fueling distance education and also remote teaching through non-classroom classes.

The development of this research sought to evaluate the process of interaction and interactivity, in asynchronous communication between teacher and student, in the AVA and in the Classroom platform (google platform) in classes in the non-presential modality in a public Institution of Higher Education. It was possible to notice that this communication allows the manifestation of "noises" between the message posted and the interpretation and, later, the recorded return.

This friction was configured by the time difference established between the posting of the message, the student or teacher access and the posting of the response. This process is characteristic of asynchronous communication.

We highlight the importance of using a clear, detailed and welcoming language in the AVA space and in the Classroom platform (google platform) used in classes in the face-to-face modality.

It is possible to avoid the cultivation of conflicting sections, but the end of their manifestation cannot be guaranteed. A word can have variations in terms of meaning and sense, these variations being linked to the context in which the word is inserted, as well as it is interpreted by each subject involved in the process.

The distance education model has elements essential to the availability of a functional VLE, which are composed of quality materials, commitment from teachers and support groups and the continuous access of students, as well as the fulfillment of the proposed activities.

With the cultivation of a progressive and reflective relationship between these elements, it is possible to contribute to the achievement of new course proposals and, also, to understand more and more the different communication possibilities linked to AVA.

Clear and objective communication, both in distance education and in classroom classes, is essential for the teachinglearning process. However, the study on this theme is incipient. Thus, with the changes in the pedagogical process arising from social isolation, caused by COVID-19, it is necessary to carry out research that makes explicit new technological tools for use in the educational scenario.

\section{References}

Alexandre, A. F. (2009). A Distincao Metodologica Entre Qualidade E Quantidade Na Pratica Da Pesquisa. In: Alexandre, Agripa Faria. Metodologia Científica E Educacao. Florianopolis: Ed. Da Ufsc, 91- 101.

Azevedo, M. J. L. (2011). Mediacao De Conflitos. recovered in: http://www.naincerteza.com/site/Page4/Files/Mediacao.pdf

Belloni, M. L. (2009). Da Tecnologia A Comunicacao Educacional. In: Belloni, Maria Luiza. O Que E MídiaEducacao. 3.Ed. Ver. Campinas, Sp: Autores Associados, 13 - 29.

Brasil. Decreto 5.622 De19 De Dezembro De 2005 Regulamenta O Art. 80 Da Lei No 9.394, De 20 De Dezembro De 1996. recovered in: http://portal.mec.gov.br/Sesu/Arquivos/Pdf/Portarias/Dec5.622.Pdf.

Bohn, Carla S; Luz, Ana Maria L. Da. E Luz Filho, Sílvio S. Da. Mídia (2010), Gestao Do Conhecimento E Cognicao Como Um Guia Para Uma Gestao Empreendedora Na Inclusao Social De Educacao Digital. In: Costa, Edemir; Ribas, Julio Cesar Da C. E Luz Filho, Sílvio Serafim Da. (Org.) Mídia, Educacao E Subjetividade: Disseminando O Conhecimento. 1.Ed. Florianopolis: Tribo Da Ilha, 1, 21 - 45.

Kenski, V.M (2004) Tecnologia E Ensino Presencial A Distancia. 6aed. Sao Paulo: Papirus. 
Lapolli, Mariana; Busarello, Raul I; Luz Filho, Sílvio S. Da; Vanzin, T. E Ulbricht, Vania R.(2011) Subjetividade Na Construcao De Narrativas Hipermidiaticas: O Caso Da Banda Hail The Villain. In: Costa, Edemir; Ribas, Julio Cesar Da C. E Luz Filho, Sílvio S. Da. (Org.) Mídia, Educacao E Subjetividade: Disseminando O Conhecimento. 1.Ed. Florianopolis: Tribo Da Ilha, 2, 229 - 252.

Levy, P. (1999) Cibercultura. Sao Paulo: Editora 34, 1999.

Machado, A.B. (2020) Educacao Em Tempos De Covid-19: Desafios E Possibilidades. In: Tiago Eurico De Lacerda; Anderson Luiz Tedesco. (Org.). Revisao Sistematica: Educacao Em Tempos De Covid-19. 1ed.Curitiba: Bagai, $1,98-112$.

Machado, A. B..;Fialho. M.(2013) Analise Do Papel Do Professor Orientador No Processo De Orientacao A Distancia: Um Estudo De Caso Comparativo Entre Instituicao Publica E Privada. International Journal of Knowledge Engineering and Management, 2, 37-63.

Menezes, E. T De. E Santos, T. H (2002). Comunicacao Síncrona (Verbete). Dicionario Interativo Da Educacao Brasileira - Educabrasil. Sao Paulo: Midiamix Editora, recovered in: http://www.educabrasil.com.br/Eb/Dic/Dicionario.Asp?Id=202

Moscovici, F. 2008. Energia No Grupo: Tensao E Conflito Onterpessoal. In: Moscovici, Fela. Desenvolvimento Interpessoal: Treinamento Em Grupo. 17th Ed. Rio De Janeiro: Jose Olympio, 212 - 227.

Okada, A. L. P. E Santos, Edmea O. Dos. (2011) Comunicacao Educativa No Ciberespaco: Utilizando Interfaces Gratuitas. recovered in: http://people.kmi.open.ac.uk/Ale/Papers/A02intercom2003.Pdf

Possari, L. H. (2009) V. Producao De Material Didatico Para A Ead. In: Possari, Lucia Helena V. E Neder, Maria Lucia C. Material Didatico Para A Ead: Processo De Producao. Cuiaba: Ed. Ufmt, 47 - 62.

Trivinos, A. N. S. (2011). Pesquisa Qualitativa. In: Trivinos, Augusto N. Silva. Introducao A Pesquisa Em Ciencias Sociais: A Pesquisa Qualitativa Em Educacao. ${ }^{\text {st }}$ Ed. 20. Reimpr. Sao Paulo: Atlas, 116 - 175. 